\title{
IMPLEMENTASI PENDEKATAN DISCOVERY LEARNING DALAM LAYANAN INFORMASI FORMAT KLASIKAL
}

\author{
Erfan Ramadhani ${ }^{1}$, Ramtia Darma Putri ${ }^{2}$ \\ Universitas PGRI Palembang ${ }^{1}$ \\ Email: erfankonselor@gmail.com \\ Universitas PGRI Palembang ${ }^{2}$ \\ Email: tyadhuarrma27@gmail.com
}

\begin{abstract}
ABSTRAK
Pemanfaatan perkembangan teknologi kearah yang negatif mengakibatkan munculnya berbagai masalah diantaranya masalah penggunaan smartphone. Penggunaan smartphone yang salah dalam hal ini adalah penyebaran informasi yang tidak benar atau sering dikenal berita hoax. Permasalahan tersebut harus diatasi dengan pemberian layanan informasi format klasikal bermuatan pendekatan discovery learning. Informasi yang diberikan diharapkan memberikan pemahaman kepada siswa dalam mengatasi masalah pemanfaatan smartphone, sehingga pemberian informasi tersebut dapat memberikan efek yang positif kepada siswa dan terhindar dari penyampaian berita hoax.
\end{abstract}

Kata Kunci: Pendekatan Discovery Learning, Layanan Informasi, Format Klasikal

IMPLEMENTATION OF DISCOVERY LEARNING APPROACH TO CLASICAL FORMAT INFORMATION SERVICES

\begin{abstract}
The use of technological developments towards the negative leads to the emergence of various problems including the problem of smartphone use. Incorrect use of smartphones in this case is the dissemination of information that is not true or often known as hoax news. These problems must be overcome by providing classical format information services with a discovery learning approach. The information provided is expected to provide an understanding to students in addressing the problem of using smartphones, so that the provision of such information can have a positive effect on students and avoid the delivery of hoax news.
\end{abstract}

Keywords: Discovery Learning Approach, Information Service, Classical Format 


\section{PENDAHULUAN}

Kemajuan teknologi yang begitu pesat sangat memiliki efek terhadap perkembangan kehidupan bangsa dalam berbagai aspek. Pesatnya perkembangan teknologi memudahkan masyarakat menjalankan aktivitas sehari-hari. Aktivitas yang dilakukan masyarakat diantaranya adalah berinteraksi langsung atau tatap muka. Majunya perkembangan teknologi membuat masyarkat mudah dalam melaksanakan komunikasi. Komunikasi yang dilakukan mengunakan media telekomunikasi atau sering dikenal dengan smartphone. Penggunaan smartphone pada saat ini membuat perubahan yang sangat penting bagi kehidupan masyarakat. Perubahan yang terlihat saat ini adalah mudahnya mobalitas komunikasi masyarakat dalam menjalankan aktifitas sehari-hari. Selanjutnya dengan perkembangan tersebut masyarakat sangat terbantu dengan adanya pengunaan smartphone. Kemajuan teknologi ini dapat dikatakan sangat positif karena membantu kehidupan masyarakat apabila dimanfaatkan dengan baik. Bertitik tolak dari kemajuan teknologi ini juga masih sangat banyak efek negatif yang dimunculkan diantaranya penyebaran berita hoax.

Berita hoax menurut Dahlan M Alwi (dalam Handry. M, 2017) adalah kabar bohong yang telah direncanakan oleh penyebarnya, atau kabar yang telah dimanipulasi bertujuan untuk memberikan pengakuan dan pemahaman yang salah. Selanjutnya, menurut Hasan. A (dalam kamus besar bahasa Indonesia, 2017) berita hoax adalah berita bohong yang dibuat dengan tujuan yang jahat. Berdasarkan pengertian tersebut dapat disimpulkan bahwa pemanfaatan perkembagan teknologi dengan baik sangatlah penting. Pemanfaatan teknologi ini berkaitan dengan kecakapan atau kemampuan masyarakat dalam menyaring informasi yang diterima. Apabila informasi yang diterima masyarakat belum dipastikan kebenaranya, selanjutnya diteruskan kepada orang lain sehinga orang lain terpengaruh oleh berita tersebut maka pemberi informasi yang pertama dapat dikatakan pemberi informasi hoax.

Pemberi informasi hoax yang menyebabkan ujaran kebencian pada masyarakat akan berdampak negatif. Pemerintah telah menegaskan apabila seseorang menyebarkan berita hoax akan terancam pasal 28 ayat 1 undang-undang informasi 
dan transaksi elektronik atau undang-undang ITE. Selanjutnya, Rikwanto (dalam Rezki, 2016) mengungkapkan bahwa apabila masyrakat menyebarkan informasi yang tidak benar maka akan diancam pidana 6 tahun dan denda 1 miliar. Berdasarkan uraian tersebut dapat disimpulkan bahwa pentingnya penyaringan informasi yang diterima sehingga tidak terjebak pada berita hoax.

Permasalahan yang muncul dari pemanfaatan perkembangan teknologi yang kurang baik tersebut perlu diatasi. Cara mengatsi masalah tersebut adalah dengan pemberian pemahaman dan keterampilan pada pengguna smartphone. Penguna smartphone dimasyarakat sangatlah menjamur terutama pada anak-anak dan remaja. Apabila anak-anak dan remaja kurang diperhatikan atau diawasi oleh orangtua dalam penggunaanya maka dihawatirkan akan dapat menyebarkan berita hoax. Permasalahan ini apabila dibiarkan akan berdampak negatif pada perkembangan sosial anak dilingkungan masyarakat.

Berdasarkan masalah di atas, peran keluarga, sekolah dan masyarakat dalam mendampingi anak menggunakan smartphone sangat penting. Salahsatu peran sekolah adalah dengan mengawasi siswa dalam pemanfaatan pengunaan smartphone. Hal lain yang harus diberikan kepada siswa adalah pemahaman atau informasi dalam penggunaan smartphone. Informasi yang diberikan dapat secara langsung dalam bentuk dinamika kelompok atau dengan cara klasikal. Pemberian informasi dalam format klasikal sangat menarik dilakukan apabila menggunakan pendekatan discovery learning. Berdasarkan uraian sebelumnya, masalah perkembangan teknologi yang tidak dapat dimanfaatkan dengan baik dan memunculkan berita hoax perlu diatasi. Cara mengatsi masalah tersebut adalah dengan pemberian informasi secara klasikal bermuatan pendekatan discovery learning. Pendekatan ini dimaksudkan akan mempermudah siswa menerima informasi yang diberikan.

\section{PENDEKATAN DISCOVERY LEARNING}

Roestiyah (2001:20) menyatakan bahwa pendekatan discovery learning adalah metode mengajar mempergunakan teknik penemuan. Pendekatan discovery learning adalah proses mental dimana siswa mengasimilasi suatu konsep atau suatu 
prinsip. Sedangkan menurut Sund (dalam Suryosubroto 2009:179) menyatakan bahwa pendekatan discovery learning adalah proses mental di mana siswa mengasimilasi suatu konsep atau suatu prinsip. Proses mental tersebut misalnya mengamati, menggolong-golongkan, membuat dugaan, menjelaskan, mengukur, membuat kesimpulan, dan sebagainya. Selanjutnya, Ramadhani (2016:41) mengungkapkan bahwa pendekatan discovery learning adalah pembelajaran yang terjadi sebagai sebuah hasil dari kegiatan siswa dalam memanipulasi objek (alat peraga), membuat struktur, dan mentransformasikan informasi, sehingga menemukan informasi/pengetahuan tentang konsep baru.

Bell (dalam Hosnan, 2014:284) mengemukakan terdapat beberapa tujuan dari pembelajaran penemuan yakni sebagai berikut.

a. Dalam penemuan siswa memiliki kesempatan untuk terlibat secara aktif dalam pembelajaran.

b. Siswa belajar menemukan pola dalam situasi konkrit maupun abstrak, sehingga siswa meramalkan informasi yang diberikan.

c. Siswa memanfaatkan strategi tanya jawab kepada Konselor maupun temantemanya dalam merumuskan penemuannya.

d. Konsep dari hasil penemuan yang didapatkan siswa lebih bermakna.

e. Hasil kegiatan yang diperoleh lebih mudah diaplikasikan.

\section{LAYANAN INFORMASI FORMAT KLASIKAL}

Prayitno (2013:9) mengungkapkan layanan informasi adalah layanan BK yang membantu siswa menerima dan memahami berbagai informasi diri, sosial, belajar, karier/jabatan, dan pendidikan lanjutan secara terarah, objektif, dan bijak. Selanjutnya, Sukardi (2007:61) mendefinisikan layanan informasi sebagai layanan bimbingan yang memungkinkan siswa dan pihak-pihak lain yang dapat memberikan pengaruh besar kepada siswa (terutama orangtua) dalam menerima dan memahami informasi yang dapat digunakan sebagai bahan pertimbangan dan mengambil keputusan. 
Selanjutnya, Winkel dan Hastuti (2010:316) mengungkapkan layanan informasi diadakan untuk membekali siswa dengan pengetahuan tentang data dan fakta dibidang pendidikan, bidang pekerjaan, bidang perkembangan diri, dan sosial, agar mereka belajar tentang lingkungan hidupnya lebih maupun mengatur dan merencanakan kehidupan sendiri.

Dari beberapa pernyataan ahli di atas, dapat disimpulkan bahwa layanan informasi adalah layanan yang memberikan informasi untuk membantu siswa sebagai bahan pertimbangan dalam mengambil suatu keputusan. Layanan informasi juga memiliki tujuan khusus yang terkait dengan fungsi-fungsi konseling. Menurut Prayitno (2004:2) fungsi pemahaman paling dominan dan paling diemban oleh layanan informasi. Adapun yang dimaksud dengan fungsi pemahaman adalah fungsi BK yang akan menghasilkan pemahaman tentang sesuatu oleh pihak-pihak tertentu sesuai dengan kepentingan pengembangan siswa. Prayitno dan Amti (2004:196) mengungkapkan Konselor sekolah harus merealisasikan lima fungsi BK yaitu: fungsi pencegahan, pamahaman, pengentasan, pemeliharaan, serta pengembangan.

Layanan informasi dapat diberikan secara individual, kelompok, jarak jauh dan klasikal. Format klasikal dinilai efektif dalam mengatasi masalah pemahaman siswa berkenaan dengan pemanfaatan smartphone. Prayitno (2012:57) mengungkapkan bahwa format yang umum dalam layanan informasi adalah format klasikal dengan jumlah peserta yang terbatas didalam suatu kelas.

\section{PEMBAHASAN}

Permasalahan yang muncul yang disebabkan oleh perkembangan teknologi dan pemanfaatan smartphone yang tidak tepat akan berdampak negatif pada penggunanya. Dampak negatif tersebut akan muncul apabila tidak diberikan

pemahaman kepada penguna smartphone. Penguna smartphone dalam hal ini adalah masyarakat umum terutama siswa. Apabila Siswa yang menggunakan smartphone tidak diberikan pemahaman berkaitan dengan cara pemanfaatnnya maka ditakutkan akan menimbulkan berita hoax yang merugikan oranglain dan dirinya. Salah satu cara yang dapat dilakukan dalam mengatasi masalah tersebut adalah dengan pemberian 
informasi bermuatan pendekatan discovery learning secara klasikal. Layanan informasi menggunakan pendekatan ini mengarahkan siswa dalam mencari atau menemukan solusi yang tepat dalam mengatasi masalahanya. Menurut Ramadhani (2016) layanan informasi dinilai efektif dalam meningkatkan aspirasi karier siswa. Hasil penelitian tersebut dapat menjadi acuan bahwa layanan informasi juga dapat memberikan pemahaman siswa terhadap penggunaan smartphone. Selanjutnya, Ramadhani (2017) mengemukakan bahwa layanan infomasi memiliki tujuan untuk mengarahkan seseorang mampu memahami keadaan dirinya. Setelah memapu memahami keadaan dirinya maka informasi yang diterima siswa dapat dicerna dengan baik serta diterapkanya dalam pemanfaatan smartphone.

Ramadhani, E, Putri, R.D, \& Istiqoma, V.A. (2018) mengungkapkan bahwa layanan informasi efektif dalam mengurangi tingkat prokrastinasi akademik mahasiswa dalam mengerjakan skripsi. Penelitian Ramadhani, E, Putri, R.D, \& Istiqoma, V.A. (2018) merupakan suatu rujukan bahwa layanan informasi juga dapat mengurangi tingkat prokrastinasi akademik mahasiswa mengerjakan skripsi. Selanjutnya, Penelitian Ramadhani, E. \& Sari, K (2018) menunjukkan bahwa secara umum layanan bimbingan kelompok menggunakan pendekatan discovery learning efektif dalam mengurangi prokrastinasi akademik mahasiswa dalam mengerjakan skripsi. Berdasarkan penelitian tersebut dapat disimpulkan bahwa pendekatan discovery learning dapat diterapkan pada berbagai layanan, terutama pada layanan informasi format klasikal.

\section{KESIMPULAN}

Berdsarkan uraian di atas dapat disimpulkan hal-hal berikut ini:

a. Perkembangan teknologi tidak selalu berdampak positif hal itu ditandai dengan banyaknya penyebaran informasi hoax pada masyrakat mengunakan media smartphone.

b. Layanan informasi format klasikal menggunakan pendekatan discovery learning dapat mengatasi berbagai masalah. 
c. Pendekatan discovery learning dinilai efektif dalam berbagai jenis layanan terutama layanan informasi format klasikal.

d. Siswa diharapkan mampu menyikapi perkembangan teknologi dengan cara positif sehingga tidak merugikan masyarakat dan dirinya.

\section{DAFTAR PUSTAKA}

Handry. M. 2017. Ahli: "Hoax” Merupakan Kabar yang Direncanakan. Antaranews. Tersedia (online) https://www.antaranews.com/berita/606085/ahli-hoaxmerupakan-kabar-yang-direncanakan, diakses 25 Agustus 2018.

Hasan. A. 2007. Kamus Besar Bahasa Indonesia. Jakarta: Balai Pustaka.

Hosnan, M. 2014. Pendekatan Saintifik dan Kontekstual dalam Pembelajaran Abad 21: Kunci sukses implementasi kurikulum 2013. Bogor: Ghalia Indonesia.

Prayitno. 2004. Seri Layanan Konseling L. 1-9. Padang: UNP Press.

Prayitno. 2012. Jenis Layanan dan Kegiatan Pendukung Konseling. Padang: Program PPK UNP.

Prayitno. 2013. Konseling Integritas. Padang: FIP UNP.

Ramadhani, E. 2016. Efektivitas Layanan Informasi Menggunakan Pendekatan Discovery Learning dalam Meningkatkan Aspirasi Karier Siswa. Tesis tidak diterbitkan. Prodi S2 BK FIP UNP.

Ramadhani, E. 2017. Efektivitas Layanan Infomasi dalam Meningkatkan Aspirasi Karir Siswa. Jurnal Wahana Didaktika.Volume 15 Nomor 2: 57-66. FKIP Universitas PGRI Palembang.

Ramadhani, E, Putri, R.D, \& Istiqoma, V.A. 2018. Effectiveness of Information Services to Reduce Student Academic Procrastination in Working Thesis (Experiment Study on Student of Guidance and Counseling Universitas PGRI Palembang). Prosiding Dosen Universitas PGRI Palembang Edisi 18. Jurnal Dosen Universitas PGRI Palembang.

Ramadhani, E. \& Sari K. 2018. Efektivitas Layanan Bimbingan Kelompok Menggunakan Pendekatan Discovery Learning untuk Mengurangi Prokrastinasi Akademik Mahasiswa Mengerjakan Skripsi. Jurnal Wahana Didaktika. Volume 16 Nomor 2. FKIP Universitas PGRI Palembang.

Rezki. 2016. Mabes Polri: Penyebar Hoax Diancam Hukuman 6 Tahun Penjara. Tempo.co. Tersedia (online) https://nasional.tempo.co/read/821644/mabespolri-penyebar-hoax-diancam-hukuman-6-tahun-penjara/full\&view=ok, diakses 25 Agustus 2018.

Roestiyah. 2001. Strategi Belajar Mengajar. Jakarta: Rineka Cipta. 
Sukardi. 2007. Pengantar Pelaksanaan Program Bimbingan dan Konseling di Sekolah. Jakarta: Rineka Cipta.

Suryosubroto. 2009. Proses Belajar Mengajar di Sekolah. Jakarta: Rineka Cipta.

Winkel, W.S. \& Hastuti. 2010. Bimbingan dan Konseling di Institusi Pendidikan. Jakarta: Gramedia Widiasarana. 